\title{
Magnetic Resonance Imaging - a powerful tool for Tissue Engineering. An updated review.
}

\section{Imagem por Ressonância Magnética - uma ferramenta poderosa para a Engenharia de Tecidos. Uma revisão atualizada}

\author{
Hugo A. Ferreira ${ }^{1}$, H. Silva ${ }^{2,3}$ \& L.M. Rodrigues ${ }^{2,3}$ \\ ${ }^{1}$ Instituto de Biofísica e Engenharia Biomédica, Faculdade de Ciências da Universidade de Lisboa, \\ Lisboa, Portugal \\ ${ }^{2}$ CBIOS - Universidade Lusófona's Research Center for Health Science and Technologies (UDE), \\ Campo Grande, 376, 1749-024, Lisboa, Portugal \\ ${ }^{3}$ Pharmacol. Sc Depart - Universidade de Lisboa, School of Pharmacy, Lisboa, Portugal \\ Email: hhferreira@fc.ul.pt
}

\begin{abstract}
Tissue engineering (TE) is a fast growing field of research that aims at creating functional biological replacements for the human body. It requires specific conditions favorable for tissue regeneration, and the outcome of the engineered tissue must be objectively assessed. Magnetic Resonance Imaging (MRI) is one of the most promising tools to do this. This review discusses the most recent publications concerning the several MRI-based techniques available for the assessment of engineered tissue constructs and the current applications of MRI in TE.
\end{abstract}

Keywords: Tissue Engineering; MRI; Cell Condition; Scaffold.

\begin{abstract}
Resumo
A Engenharia de Tecidos (ET) é uma área de investigação crescente que se direciona à criação de substitutos biológicos funcionais para vários tecidos do corpo humano. Requer condições específicas favoráveis para a regeneração de tecidos, e o resultado do tecido engenheirado deve ser avaliado objetivamente. A Imagem por Ressonância Magnética (IRM) é uma das técnicas mais promissoras para este efeito. Esta revisão discute as publicações mais recentes acerca das várias técnicas baseadas na IRM disponíveis para a avaliação de tecidos engenheirados e as presentes aplicações da IRM na ET.
\end{abstract}

Palavras-chave: Engenharia de Tecidos, IRM, Condição Celular, Suportes 


\section{Introduction}

Organ failure is treated either with surgical transplantation or replacement of living tissue with mechanical/electrical devices such as artificial joints, vascular stents, or pacemakers ${ }^{[1]}$. Transplants, however, rely on the availability of a compatible donor while biomechanical devices wear out and must be replaced ${ }^{[1]}$ and could also induce inflammatory response in the host ${ }^{[2]}$. A third option for these patients is emerging from the recent field of research called Tissue Engineering ${ }^{[1]}$.

Tissue Engineering employs concepts of cell biology, transplantation, materials science and biomedical engineering to develop tissue-like structures that can replace injured tissues and failing organs ${ }^{[3]}$. Current medical practice could use engineered tissues to treat a variety of diseases (for example, skin ulcers, joint defects, diabetes, cardiac valve failure, osteogenic tissue loss, and liver disease $)^{[4]}$.

Successful tissue engineering requires healthy expandable cells, a porous biocompatible scaffold, biochemical growth factors, and a favorable physiological environment for tissue regeneration ${ }^{[1]}$.

These biological substitutes are assembled de novo from a three-dimensional scaffold which is imbedded with cells and essential growth and differentiation factors that allow them to proliferate and differentiate ${ }^{[1]}$. The tissue-engineered products may be fully functional at the time of implantation or have the potential to integrate and form the expected functional tissue upon implantation $^{[2]}$.

\section{Introdução}

\section{Engenharia de Tecidos}

A falência de um órgão é tratada com transplantação cirúrgica ou com substituição de tecido vivo por dispositivos mecânicos/elétricos como articulações artificiais, stents vasculares ou pacemakers ${ }^{[1]}$. Contudo, os transplantes dependem da disponibilidade de um dador compatível enquanto que os dispositivos biomecânicos sofrem desgaste e têm de ser substituídos ${ }^{[1]}$ e podem também provocar uma resposta inflamatória no hospedeiro ${ }^{[2]}$. Uma terceira opção para estes doentes está a emergir da recente área de investigação chamada Engenharia de Tecidos ${ }^{[1]}$.

A TE emprega conceitos da biologia celular, transplantação, ciência de materiais e engenharia biomédica para desenvolver estruturas semelhantes a tecidos que possam substituir tecidos lesados e órgãos em falência ${ }^{\left[{ }^{[3]}\right.}$. A prática médica atual poderia usar tecidos engenheirados para tratar uma variedade de patologias (por exemplo, úlceras cutâneas, defeitos articulares, diabetes, insuficiência valvular cardíaca, perda tecidular osteogénica e doença hepática) ${ }^{[4]}$.

A Engenharia de Tecidos bem sucedida requer células saudáveis expansíveis, um suporte poroso biocompatível, fatores bioquímicos de crescimento, e um ambiente fisiológico favorável à regeneração tecidular ${ }^{[1]}$.

Estes substitutos biológicos são construídos de novo a partir de um suporte tridimensional que é embutido com células e fatores essenciais de crescimento e diferenciação que as permitem proliferar e diferenciar-se ${ }^{[1]}$.

Estes produtos de tecido engenheirado podem estar completamente funcionais no momento da implantação ou apresentar o potencial de integrar e formar o tecido funcional esperado após a implantação ${ }^{[2]}$.

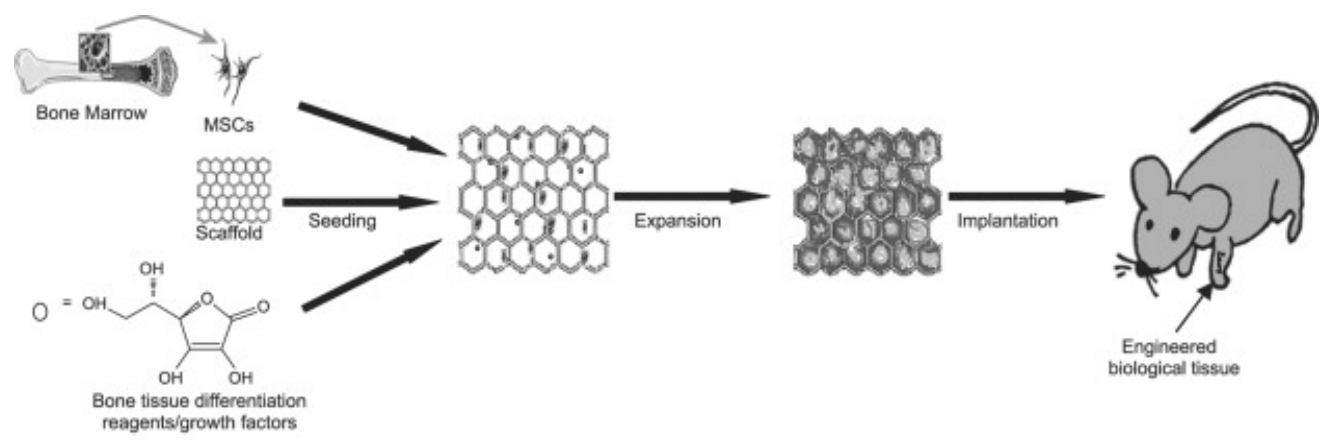

Figure 1- Flow diagram for bone tissue engineering. After isolation from bone marrow, mesenchymal stem cells proliferate in vitro. The cells are then seeded into the biocompatible scaffold along with growth and differentiation factors. The cells continue to grow and differentiate in an incubator or bioreactor. Upon maturity, the engineered tissue is transplanted into the animal or patient. Based on Ref [1].

Figura 1- Diagrama de fluxo para a engenharia de tecido ósseo. Após o isolamento da medula óssea, células estaminais mesenquimatosas proliferam in vitro. As células são depois semeadas no suporte biocompatível juntamente com fatores de crescimento e diferenciação. As células continuam a crescer e a diferenciar-se num incubador ou biorreator. Após a maturação, o tecido assim construído é transplantado para o animal ou o doente. Baseado na Ref [1]. 


\section{Cell sources}

Cell sources, based on their origin, fall into three categories - autologous cells from the patient, allogeneic cells from another human donor, and xenogeneic cells from other species ${ }^{[5]}$. The use of autologous cells avoids the risks of immunological responses such as rejections and viral infections ${ }^{[6]}$. Autologous cells can be harvested by biopsy, a technique that applies to most organ structures, such as skin, liver, heart, blood vessels, bone, bone marrow and cartilage. However, for some tissues or organs, such as heart valves, direct biopsies are not feasible and related harvest sites must be considered, such as peripheral vein segments. For neural tissues neither direct nor indirect biopsies are feasible ${ }^{[6]}$. One approach to solve this cell-source difficulty is the isolation of stem cells ${ }^{[6]}$. Stem cells might be derived either from fetal tissue or from adult tissue. The use of fetal tissue raises potential immunological and ethical issues, however, and recent studies have focused on cells derived from autologous bone marrow or stem cells and progenitor cells from the circulation ${ }^{[6]}$. While stem cells are pluripotent, which implies the ability to differentiate into virtually every cell type ${ }^{[7]}$, progenitor cells are more differentiated than stem cells and are best described as multipotent ${ }^{[8]}$.

\section{Scaffold classification and function}

Generally, three classes of biomaterials have been used for engineering tissues and organs - naturally derived materials, such as collagen and alginate; acellular tissue matrices, such as bladder submucosa and smallintestinal submucosa; and synthetic polymers, such as polyglycolic acid (PGA), polylactic acid (PLA), and polylactic-coglycolic acid (PLGA) ${ }^{[3]}$. The acellular tissue matrices are either allogeneic or xenogeneic tissues that are decellularized by enzymatic or detergent methods. They are theoretically biodegradable and bioresorbable and might be an appropriate scaffold for cell seeding ${ }^{[6]}$. The matrices slowly degrade upon implantation and are replaced and remodelled by ECM proteins synthesized and secreted by transplanted or ingrowing cells ${ }^{[9]}$. The synthetic polymers are usually polyesters of naturally occurring $\alpha$-hydroxy acids such as PGA, PLA and PLGA. The degradation products of these polyesters are nontoxic, natural metabolites that are eventually eliminated from the body in the form of carbon dioxide and water ${ }^{[10]}$. One drawback of the synthetic polymers is lack of biologic recognition ${ }^{[3]}$.

In TE biomaterials replicate the biologic and

\section{Fontes celulares}

As fontes celulares, baseadas na sua origem, caem em três categorias: células autólogas do doente, células alogeneicas de outro dador humano, e células xenogeneicas de outras espécies ${ }^{[5]}$. A utilização de células autólogas evita os riscos de respostas imunológicas como rejeições e infeções virais ${ }^{[6]}$.

As células autólogas podem ser colhidas por biópsia, uma técnica que se aplica à maioria das estruturas dos órgãos, como a pele, fígado, coração, vasos sanguíneos, osso, medula óssea e cartilagem. Contudo, para alguns tecidos e órgãos, como as válvulas cardíacas, biópsias diretas não são praticáveis e locais de colheita relacionados devem ser considerados, como segmentos de veias periféricas. Para tecidos neurais nem biópsias diretas nem indiretas são praticáveis ${ }^{[6]}$.

Uma abordagem para ultrapassar esta dificuldade da fonte celular é o isolamento de células estaminais ${ }^{[6]}$. Células estaminais podem ser derivadas de tecido fetal ou de tecido adulto. Contudo, a utilização de tecido fetal levanta potenciais questões imunológicas e éticas e estudos recentes têm-se focado em células derivadas de medula óssea autóloga ou em células estaminais ou precursoras da circulação sanguínea ${ }^{[6]}$. Enquanto que as células estaminais são pluripotentes, o que implica a capacidade de se diferenciarem em virtualmente todos os tipos celulares ${ }^{[7]}$, as células progenitoras são mais diferenciadas que as estaminais e são melhor descritas como pluripotentes ${ }^{[8]}$.

\section{Classificação e funções do suporte}

Em geral, têm sido usadas 3 classes de biomateriais para a engenharia de tecidos e órgãos: derivados de materiais naturais, como o colagénio e o alginato; matrizes tecidulares acelulares, como a submucosa de bexiga e intestino delgado; e polímeros sintéticos, como o ácido poliglicólico (APG), ácido poliláctico (APL) e ácido poliláctico-coglicólico (APLG) ${ }^{[3]}$.

As matrizes tecidulares acelulares são tecidos alogeneicos ou xenogeneicos que são descelularizados por métodos enzimáticos ou detergentes. São teoricamente biodegradáveis e bioreabsorbíveis e podem ser suportes apropriados para a cultura celular ${ }^{[6]}$. As matrizes degradam-se lentamente após a implantação e são substituídas e remodeladas por proteínas da matriz extracelular (MEC) secretadas por células transplantadas ou em crescimento ${ }^{[9]}$.

Os polímeros sintéticos são usualmente poliésteres de $\alpha$-hidroxiácidos naturais como APG, APL e APLG. Os produtos de degradação destes poliésteres são metabolitos naturais, não tóxicos, que são eventualmente eliminados do corpo na forma de dióxido de carbono e água ${ }^{[10]}$. Uma desvantagem dos 
mechanical function of the native extracellular matrix (ECM) found in tissues in the body by serving as an artificial ECM ${ }^{[3]}$. They provide a 3-dimensional space for the cells to form into new tissues with appropriate structure and function ${ }^{[3]}$, and also can allow for the delivery of cells and appropriate bioactive factors (for example, cell adhesion peptides, growth factors), to desired sites in the body ${ }^{[2,11]}$. As the majority of mammalian cell types are anchorage-dependent and will die if no cell-adhesion substrate is available, biomaterials also provide a cell-adhesion substrate. Biomaterials can also provide mechanical support against in vivo forces such that the predefined 3dimensional structure is maintained during tissue development ${ }^{[1,3]}$.

\section{Assessing the outcome of TE}

There are many techniques capable of rendering 3D images of tissues and thus capable of assessing the outcome of an engineered tissue, such as angiography, fluoroscopy, mammography, MRI, computed tomography (CT), stereophotogrammetry, and ultrasound techniques ${ }^{[12]}$.

Magnetic resonance imaging (MRI) is a noninvasive experimental technique that is capable of characterizing multiple physical phenomena in living tissues ${ }^{[13]}$. As tissues develop, die, or regenerate, the local environment of the tissue water - the source of the MR signal-changes. Such changes are reflected in MR images through local variations in the amount of tissue water, its physical state (e.g., freely diffusing or protein bound), and its nuclear magnetic resonance (NMR) relaxation times $\left(T_{1}\right.$ and $\left.T_{2}\right){ }^{[1]}$. It also presents the advantage of not using ionizing radiation, which makes it safer than $\mathrm{CT}^{[12]}$.

We reviewed 137 papers published in the last 5 years. The most frequently used MRI techniques were $T_{1}, T_{2}$ and $\mathrm{T}_{2}{ }^{*}$ mapping ${ }^{[1]}$, magnetic resonance spectroscopy ${ }^{[14]}$ and elastography ${ }^{[15]}$. Some studies focused on constructs ${ }^{[15]}$, while others on tracking stem cells in vivo ${ }^{[16]}$ and molecule detection ${ }^{[17]}$.

The most common MRI applications focused on joint cartilage ${ }^{[18]}$ intervertebral disc ${ }^{[19]}$, bone ${ }^{[14]}$, heart regeneration ${ }^{[16]}$ and angiogenesis ${ }^{[17]}$. polímeros sintéticos é a falta de reconhecimento biológico $^{[3]}$.

$\mathrm{Na}$ ET os biomateriais replica as funções biológicas e mecânicas da MEC encontrada nos tecidos do corpo ao servir de MEC artificial ${ }^{[3]}$. Eles fornecem um espaço tridimensional para as células se formarem em novos tecidos com estrutura e função apropriada ${ }^{[3]}$, e podem também permitir a entrega de células e fatores bioativos apropriados (por exemplo, péptidos de adesão celular, fatores de crescimento) para os locais desejados no corpo ${ }^{[2,11]}$. Como a maioria dos tipos de células mamíferas são dependentes de ancoragem e morrerão se não existir um substrato de adesão celular disponível, os biomateriais também fornecem um substrato de adesão celular. Os biomateriais também podem fornecer suporte mecânico contra forças in vivo tal que a estrutura tridimensional predefinida é mantida durante o desenvolvimento tecidular ${ }^{[1,3]}$.

\section{Avaliação dos resultados da ET}

Existem diversas técnicas capazes de produzir imagens tridimensionais de tecidos e, assim, serem capazes de avaliar o resultado de um tecido engenheirado, tal como a angiografia, fluoroscopia, mamogragfia, IRM, tomografia computorizada (TC), estereofotogrametria e técnicas de ultrassons ${ }^{[12]}$.

A Imagem por Ressonância Magnética (IRM) é uma técnica experimental não invasiva capaz de caracterizar múltiplos fenómenos nos tecidos vivos ${ }^{[13]}$. Estas alterações estruturais e funcionais afetam as propriedades tecidulares de água - a fonte do sinal de ressonância magnética (RM) - o seu estado físico (por exemplo, livremente difusível ou ligado a proteínas) e os seus tempos de relaxação $\left(T_{1}\right.$ e $\left.T_{2}\right)$ de ressonância magnética nuclear (RMN) ${ }^{[1]}$ Apresenta também a vantagem de não usar radiação ionizante, tornando-se mais segura que a $\mathrm{TC}^{[12]}$.

A Imagem por Ressonância Magnética (IRM) é uma técnica experimental não invasiva capaz de caracterizar múltiplos fenómenos nos tecidos vivos ${ }^{[13]}$. À medida que os tecidos se desenvolvem, morrem ou se regeneram, o ambiente local da água do tecido - a fonte do sinal de RM - altera-se. Essas alterações refletem-se nas imagens de RM através de variações locais na quantidade de água tecidular, do seu estado físico (por exemplo, livremente difusível ou ligada a proteínas), e os seus tempos de relaxação $\left(T_{1}\right.$ e $\left.T_{2}\right)$ de ressonância magnética nuclear (RMN).

Revimos 137 artigos publicados nos últimos 5 anos. A maioria das técnicas de IRM foram mapeamento de $T_{1}, T_{2} e$ $\mathrm{T}_{2}{ }^{[1]}$, espectroscopia de ressonância magnética ${ }^{[14]} \mathrm{e}$ 
elastografia ${ }^{[15]}$. Alguns estudos focaram-se em tecidos construídos ${ }^{[15]}$, enquanto outros se focaram no rastreamento de células estaminais in vivo ${ }^{[16]}$ e deteção molecular ${ }^{[17]}$.

As aplicações mais comuns da IRM focaram-se na cartilagem articular ${ }^{[18]}$, disco intervertebral ${ }^{[19]}$, osso ${ }^{[14]}$, regeneração cardíaca ${ }^{[16]}$ e angiogénese ${ }^{[17]}$.

\section{Bone and cartilage regeneration}

MRI-based techniques have been used to study the cartilage function. Such techniques include tag registration ${ }^{[20]}$ and phase contrast ${ }^{[21]}$ which measure tissue deformation, and the Delayed GadoliniumEnhanced MRI of Cartilage (dGEMRIC) technique which provides spatial information of glycosaminoglycan (GAG) content using $T_{1}$-relaxation time measurements after penetration of the hydrophilic contrast agent Gd-DTPA ${ }^{2-[22]}$.

Furthermore the displacement-encoding by stimulated echo and fast spin echo (DENSE-FSE) technique, also based on MRI, has been considered appropriate for characterizing tissue-level deformations noninvasively in engineered tissue ${ }^{[18]}$.

Weber et al. (2012) used MRI in combination with solid-state nuclear magnetic resonance (NMR) spectroscopy to visualize and evaluate the extracellular matrix formation in poly(D,L-lactide-co-glycolide) (PLGA) rat bone implants ${ }^{[14]}$. Previously the same techniques were employed by Neves et al. (2006) in the evaluation of the properties of different scaffold geometries for the production of bioartificial meniscal cartilage constructs $^{[23]}$.

MRI $\mathrm{T}_{2}$ relaxation time was used to assess the integration of a hydrogel scaffold in a cartilage ${ }^{[24]}$. Later, Ramaswamy et al. (2008) also used MRI $\mathrm{T}_{2}$ relaxation time to quantify the amount of repair tissue that fills surgically-induced chondral defects in the rabbit $^{[25]}$.

\section{Cell tracking}

MRI has also been used to track and evaluate the viability of implanted cells within an engineered construct, both in vitro and in vivo ${ }^{[16,19]}$. In an in vitro study Saldanha et al. (2008) labeled mesenchymal cells seeded onto rat intervertebral disk constructs with ferumoxide-based contrast agent and quantified the signal intensity loss using MRI relaxation parameters $\left(\mathrm{T}_{1}, \mathrm{~T}_{2} \text {, and } \mathrm{T}_{2}{ }^{*}\right)^{[19]}$.

Harrington et al. (2011) surgically implanted into the inferior vena cava of mice, a graft consisting of a scaffold seeded with murine macrophages which were labeled with ultrasmall superparamagnetic iron oxide

\section{Regeneração óssea e cartilagínea}

Têm sido usadas técnicas baseadas em IRM para estudar a função cartilagínea. Essas técnicas incluem tag registration ${ }^{[20]}$ e contraste de fase ${ }^{[21]}$ que medem o tempo de deformação, e a técnica de Delayed Gadolinium-Enhanced MRI of Cartilage (dGEMRIC) que fornece informação espacial do conteúdo de glicosaminoglicanos (GAG) usando medições do tempo $T_{1}$ de relaxação após a penetração do agente de contraste hidrofílico Gd-DTPA ${ }^{2-[22]}$.

Além disso, a técnica de displacement-encoding by stimulated echo and fast spin echo (DENSE-FSE), também baseada na IRM, tem sido considerada apropriada para caracterizar de forma não-invasiva deformações ao nível tecidular em tecido engenheirado [18]

Weber et al. (2012) usaram a IRM em combinação com a espectroscopia de ressonância magnética nuclear (RMN) em estado sólido para visualizar e avaliar a formação de matriz extracelular em implantes de APLG em osso de rato ${ }^{[14]}$. Previamente as mesmas técnicas foram empregues por Neves et al. (2006) na avaliação das propriedades de diferentes geometrias de suportes para a produção de construções de cartilagem bioartificial do menisco ${ }^{[23]}$.

$\mathrm{O}$ tempo de relaxação $T_{2}$ foi usado para avaliar a integração de um suporte de hidrogel em cartilagem ${ }^{[24]}$. Noutro estudo o mesmo parâmetro foi usado para determinar a quantidade de tecido de reparação que preencheu defeitos condrais induzidos cirurgicamente no coelho ${ }^{[25]}$.

\section{Rastreamento celular}

A IRM também tem sido utilizada para localizar e avaliar a viabilidade de células implantadas num tecido engenheirado, tanto in vitro como in vivo ${ }^{[16,19]}$. Num estudo in vitro Saldanha et al. (2008) marcaram células mesenquimatosas semeadas em discos intervertebrais de rato com agente de contraste à base de ferumóxidos $\mathrm{e}$ quantificaram a intensidade de sinal perdida usando parâmetros de relaxação de $\operatorname{IRM}\left(\mathrm{T}_{1}, \mathrm{~T}_{2} \text {, and } \mathrm{T}_{2}{ }^{*}\right)^{[19]}$.

Harrington et al. (2011) implantaram cirurgicamente na veia cava inferior de ratinhos um enxerto consistindo de um suporte semeado com macrófagos de ratinho marcados com nanopartículas ultrapequenas de óxido 
(USPIO) nanoparticles. These seeded cells were tracked with MRI, and $T_{2}$ relaxation times were evaluated $^{[26]}$.

Bollini et al. (2011) studied the in vivo potential of Endorem-labeled GFP-rAFS cells for myocardial repair by transplantation in the heart of rats with ischemia/reperfusion injury (I/R), which was subsequently monitored by MRI ${ }^{[16]}$.

Ramaswamy et al. (2012) used superparamagnetic iron oxide (SPIO) microparticles to label human vascular endothelial cells (VECs) and vascular smooth muscle cells (VSMCs), and used MRI to visualize and assess the migration of these cells in agar gel constructs, designed to be implanted in a pulmonary valve ${ }^{[27]}$.

Towner et al. (2010) used MRI-based cell tracking to assess angiogenesis. The authors developed a molecular probe for the detection of vascular endothelial growth factor receptor 2 (VEGF-R2), which is elevated during angiogenesis, in rat glioma models. The probe consisted of a magnetite-based dextran-coated nanoparticle backbone covalently bound to an anti-VEGF-R2 antibody, which was detected with molecular magnetic resonance imaging (mMRI). The results obtained in this study suggest that this method can be extended to the study of angiogenesis in tissue engineering ${ }^{[17]}$.

In another angiogenesis study, Beaumont et al. (2010) used dynamic contrast-enhanced magnetic resonance imaging (DCE-MRI) to investigate and characterize angiogenesis necessary for bone formation following the insertion of a vascular endothelial growth factor (VEGF)-impregnated tissue-engineered construct within a defect in the membranous parietal bone of a rabbit $^{[28]}$.

\section{Elastography}

Magnetic Resonance elastography (MRE) is based on the synchronization of a mechanical actuator with a phase contrast imaging pulse sequence, and is useful due to the capacity to measure tissue strain generated by sonic cyclic displacement. This technique has been extended to the microscopic scale, combining clinical MRE with stronger magnetic field gradients and smaller, more sensitive radiofrequency coils, enabling for the analysis of smaller samples, such as in vitro and in vivo tissue-engineered constructs ${ }^{[15]}$. Othman et al. (2011) used high resolution Magnetic Resonance Elastography to assess the development of osteogenic and adipogenic constructs implanted in immunodeficient nude mice ${ }^{[29]}$. férrico superparamagnético. Estas células semeadas foram rastreadas com IRM, tendo sido avaliados os tempos de relaxação $\mathrm{T}_{2}^{[26]}$.

Bollini et al. (2011) estudaram o potencial in vivo de células GFP-rAFS marcadas com Endorem para a reparação miocardíaca por transplantação no coração de ratos com lesão de isquémia-reperfusão (I/R), que foi subsequentemente monitorizada por IRM ${ }^{[16]}$.

Ramaswamy et al. (2012) usaram micropartículas de óxido férrico superparamagnético para marcar células de endotélio vascular e células de músculo liso humano, e usaram a IRM para visualizar e avaliar a migração destas células em construções de gel de agar destinadas a serem implantadas numa válvula pulmonar ${ }^{[27]}$.

Towner et al. (2010) usaram a marcação celular baseada em IRM para avaliar a angiogénese. Os autores desenvolveram uma sonda molecular para a deteção do recetor do fator de crescimento endotelial 2, que está elevado durante a angiogénese, em modelos de glioma no rato. A sonda consistiu num esqueleto de nanopartículas baseado em magnetite e recoberto com dextrano, que foi detetado com IRM molecular (IRMm). Os resultados obtidos neste estudo sugerem que este método pode ser alargado ao estudo da angiogénese na $\mathrm{ET}^{[17]}$.

Noutro estudo de angiogénese, Beaumont et al. (2010) usaram dynamic contrast-enhanced magnetic resonance imaging (DCE-MRI) para investigar e caracterizar a angiogénese necessária para a formação óssea após a inserção de uma construção impregnada de fator de crescimento endotelial vascular num defeito do osso do coelho ${ }^{[28]}$.

\section{Elastografia}

A Elastografia por Ressonância Magnética (ERM) baseia-se na sincronização de um atuador mecânico com um contraste de fase de uma sequência de pulsos de imagem, e é útil devido à capacidade de medir a tensão tecidular criada por deslocamento sónico cíclico. Esta técnica foi alargada à escala microscópica, combinando ERM clínica com gradientes de campo magnético mais fortes e bobinas de radiofrequência mais pequenas e mais sensíveis, permitindo a análise de amostrar mais pequenas, como tecidos engenheirados in vitro e in vivo ${ }^{[15]}$. Othman et al. (2011) usaram Elastografia por Ressonância Magnética de alta resolução para avaliar o desenvolvimento de tecidos osteogénicos e adipogénicos implantados em ratos nus imunodeficientes ${ }^{[29]}$. 


\section{Conclusions}

MRI is a powerful tool for assessing the properties of an engineered tissue scaffold, for visualizing and tracking seeded cells onto the scaffold and for monitoring the outcome of the implantation of a construct using in vitro and in vivo models.

\section{Conflict of Interest}

The authors declare that there is no financial or personal relationship that can be understood as representing a potential conflict of interest.

\section{Conclusões}

A IRM é uma ferramenta ponderosa para a avaliação das propriedades dos suportes tecidulares, para a visualização e rastreamento de células semeadas no suporte e para a monitorização do resultado da implantação de um tecido engenheirado usando modelos in vitro e in vivo.

\section{Conflito de Interesses}

Os autores declaram não existir qualquer relação financeira ou pessoal que possa ser entendida como representando um potencial conflito de interesses.

\section{References / Referências}

[1].Xu H, Othman SF, Magin RL. Monitoring tissue engineering using magnetic resonance imaging. J Biosci Bioeng. 2008; 106(6):515-27

[2].Chapekar MS, Tissue engineering: challenges and opportunities. J Biomed Mater Res. 2000;53(6):617-20

[3].Atala A. Regenerative medicine strategies. J Pediatr Surg. 2012;47(1):17-28

[4].Bianco P, Robey PG. Stem cells in tissue engineering. Nature 2000; 414:118-121

[5].Griffith, L.G. and Naughton, G.: Tissue engineering - current challenges and expanding opportunities. Science 2002;295, 1009-1014

[6].Stock UA, Vacanti JP. Tissue engineering: current state and prospects. Annu Rev Med. 2001;52:443-51

[7].Quarto R, Muraglia A, Corsi A, et al. 1998. Cultured bone marrow stromal cells: from bench to the clinic. Tissue Eng. 4:473

[8].Shi Q, Rafii S, Hong-DeWu M, et al. 1998. Evidence for circulating bone marrow derrived endothelial cells. Blood 92:362-67

[9].Atala A. Engineering tissues, organs and cells. J Tissue Eng Regen Med. 2007;1(2):83-96.

[10].Gilding D. Biodegradable Polymers. In: Williams D, editor. Biocompatibility of clinical implant materials. Boca Raton (Fla): CRC Press; 1981:209-32

[11].Kim BS, Mooney DJ. Development of biocompatible synthetic extracellular matrices for tissue engineering. Trends Biotechnol 1998;16:22430 .

[12].Ballyns JJ, Bonassar LJ. Image-guided tissue engineering. J Cell Mol Med. 2009. 13(8A):1428-36 [13].Haacke EM, Brown RW, Thompson MR, Venkatesan R. Magnetic Resonance Imaging: Physical Principles and Sequence Design. New York, NY: John Wiley \& Sons, Inc; 1999.

[14].Weber F, Böhme J, Scheidt HA, Gründer W, Rammelt S, Hacker M. 31P and 13C solid-state NMR spectroscopy to study collagen synthesis and biomineralization in polymer-based bone implants. NMR Biomed. 2012;25(3):464-75
[15].Othman SF, Curtis ET, Plautz SA, Pannier AK, Butler SD, Xu H. MR elastography monitoring of tissue-engineered constructs. NMR Biomed. 2012;25(3):452-63

[16].Bollini S, Pozzobon M, Nobles M, Riegler J, Dong $\mathrm{X}$, Piccoli $\mathrm{M}$ et al. In vitro and in vivo cardiomyogenic differentiation of amniotic fluid stem cells. Stem Cell Rev. 2011;7(2):364-80.

[17].Towner RA, Smith N, Asano Y, He T, Doblas S, Saunders D, et al. Molecular magnetic resonance imaging approaches used to aid in the understanding of angiogenesis in vivo: implications for tissue engineering. Tissue Eng Part A. 2010;16(2):357-64.

[18].Neu CP, Arastu HF, Curtiss S, Reddi AH. Characterization of engineered tissue construct mechanical function by magnetic resonance imaging. J Tissue Eng Regen Med. 2009;3(6):47785.

[19].Saldanha KJ, Piper SL, Ainslie KM, Kim HT, Majumdar S. Magnetic resonance imaging of iron oxide labelled stem cells: applications to tissue engineering based regeneration of the intervertebral disc. Eur Cell Mater. 2008; 16:17-25

[20].Neu CP, Hull ML, Walton JH, Buonocore MH. MRI-based technique for determining nonuniform deformations throughout the volume of articular cartilage explants. Magn Reson Med. 2005;53(2):321-8.

[21].Neu CP, Walton JH. Displacement encoding for the measurement of cartilage deformation. Magn Reson Med. 2008; 59(1):149-55.

[22].Bashir A, Gray ML, Hartke J, Burstein D. Nondestructive imaging of human cartilage glycosaminoglycan concentration by MRI. Magn Reson Med. 1999; 41(5):857-65.

[23].Neves AA, Medcalf N, Smith M, Brindle KM. Evaluation of engineered meniscal cartilage constructs based on different scaffold geometries using magnetic resonance imaging and spectroscopy. Tissue Eng. 2006;12(1):53-62.

[24].Ramaswamy S, Wang DA, Fishbein KW, Elisseeff JH, Spencer RG. An analysis of the integration between articular cartilage and nondegradable hydrogel using magnetic resonance imaging. J Biomed Mater Res B Appl Biomater. 2006;77(1):144-8

[25].Ramaswamy S, Gurkan I, Sharma B, Cascio B, Fishbein KW, Spencer RG. Assessment of tissue repair in full thickness chondral defects in the rabbit using magnetic resonance imaging transverse relaxation measurements. J Biomed Mater Res Appl Biomater. 2008; 86(2):375-80.

[26].Harrington JK, Chahboune H, Criscione JM, Hibino N, Yi T, Villalona GA, et al. Determining the fate of seeded cells in venous tissue-engineered vascular grafts using serial MRI. FASEB J. 2011;25(12):4150-61.

[27].Ramaswamy S, Schornack PA, Smelko AG, Boronyak SM, Ivanova J, Mayer JE Jr. Superparamagnetic iron oxide (SPIO) labeling efficiency and subsequent MRI tracking of native cell populations pertinent to pulmonary heart valve tissue engineering studies. NMR Biomed. 2012;25(3):410-7

[28].Beaumont M, DuVal MG, Loai Y, Farhat WA, Sándor GK, Cheng HL. Monitoring angiogenesis in soft-tissue engineered constructs for calvarium bone regeneration: an in vivo longitudinal DCE-MRI study. NMR Biomed 2010;23(1):48-55.

[29].Othman SF, Curtis ET, Xu H. In Vivo Magnetic Resonance Elastography of Mesenchymally Derived Constructs. Biological Systems Engineering: Papers and Publications. 2011; Paper 233. doi: 10.1109/ITiME.2011.6130914 